\title{
Influence of Bath Composition at Acidic pH on Electrodeposition of Nickel-Layered Silicate Nanocomposites for Corrosion Protection
}

\author{
Jeerapan Tientong, ${ }^{1}$ Casey R. Thurber, ${ }^{1}$ Nandika D'Souza, ${ }^{2}$ \\ Adel Mohamed, ${ }^{3}$ and Teresa D. Golden ${ }^{1}$ \\ ${ }^{1}$ Department of Chemistry, University of North Texas, 1155 Union Circle No. 305070, Denton, TX 76203, USA \\ ${ }^{2}$ Department of Mechanical and Energy Engineering, University of North Texas, Denton, TX 76207, USA \\ ${ }^{3}$ Center for Advanced Materials, Qatar University, P.O. Box 2713, Doha, Qatar
}

Correspondence should be addressed to Teresa D. Golden; tgolden@unt.edu

Received 29 July 2013; Revised 24 September 2013; Accepted 25 September 2013

Academic Editor: Hamilton Varela

Copyright (C) 2013 Jeerapan Tientong et al. This is an open access article distributed under the Creative Commons Attribution License, which permits unrestricted use, distribution, and reproduction in any medium, provided the original work is properly cited.

\begin{abstract}
Nickel-layered silicates were electrochemically deposited from acidic bath solutions. Citrate was used as a ligand to stabilize nickel (II) ions in the plating solution. The silicate, montmorillonite, was exfoliated by stirring in aqueous solution over 24 hours. The plating solutions were analyzed for zeta-potential, particle size, viscosity, and conductivity to investigate the effects of the composition at various pHs. The solution particles at $\mathrm{pH} 2.5(-22.2 \mathrm{mV})$ and $\mathrm{pH} 3.0(-21.9 \mathrm{mV})$ were more stable than at $\mathrm{pH} 1.6$ $(-10.1 \mathrm{mV})$ as shown by zeta-potential analysis of the nickel-citrate-montmorillonite plating solution. $E_{\text {corr }}$ for the films ranged from -0.32 to $-0.39 \mathrm{~V}$ with varying $\mathrm{pH}$ from 1.6 to 3.0 . The films were immersed in $3.5 \% \mathrm{NaCl}$ and the open circuit potential monitored for one month. The coatings deposited at $\mathrm{pH} 3.0$ were stable 13 days longer in the salt solution than the other coatings. $\mathrm{X}$-ray diffraction showed a change in the (111)/(200) ratio for the coatings at the various $\mathrm{pHs}$. The scanning electron microscopy and hardness results also support that the electrodeposition of nickel-montmorillonite at pH $3.0(234 \mathrm{GPa})$ had improved hardness and morphology compared to pH 2.5 (174 GPa) and pH 1.6 (147 GPa).
\end{abstract}

\section{Introduction}

A steady demand for enhanced coatings at a reduced cost has been the main focus in the area of corrosion for many years. Degradation of the coatings takes place because of unfavorable environmental conditions that lead to many types of corrosion [1-4]. Since it is difficult to completely stop corrosion, the best economical idea is to simply reduce the rate at which it occurs [5]. Low cost, convenience, and the ability to work at low temperatures have made electrodeposition one of the more favorable techniques to synthesize coatings [6]. The applied potential, $\mathrm{pH}$, temperature, and current all play a role in determining the morphology, structure, and composition of the coatings [6-8].

One metal commonly used to enhance corrosion resistance is nickel because of its high abundance and capability to protect against common corrosion [1-4]. Nevertheless, corrosion resistance from metal coatings tends to be unsuccessful because of reduced mechanical properties. Forming alloys, with metals such as zinc, seems to be the answer to increasing the corrosion resistance [7]. The alloyed coatings tend to enhance the corrosion resistance properties but possess mechanical properties that are comparable to the individual metals. Ceramic fortification into the metal coatings can improve mechanical properties. To increase the hardness and life of nickel coatings, different nanoparticles such as $\mathrm{TiO}_{2}$, $\mathrm{CeO}_{2}, \mathrm{SiC}$, and $\mathrm{Al}_{2} \mathrm{O}_{3}$ have been integrated into the matrix of the coating [9-14].

The ceramic compounds that are being investigated for this study are layered silicates, which possess many advantageous properties such as a high surface area, good chemical resistance, resistance to extreme temperatures, and 
resistance to $\mathrm{pH}$. Incorporation of the layered silicates into polymers [15-17] and ceramics [18, 19] to form composites has enhanced the mechanical properties. In the case of conductive polymer composite coatings, scientists have shown that layered silicates increase the resistance to corrosion [20, 21]. The incorporation of the layered silicates into the metal matrix should prove to be fruitful for enhanced resistance to corrosion and hardness in the nanocomposite coating.

In this work, nickel-layered silicate nanocomposite films were electrochemically deposited using pulsed potentiostatic conditions from an acidic plating bath containing exfoliated layered silicate to enhance adhesion to the substrate, corrosion resistance, and mechanical properties. Scanning electron microscopy (SEM) was chosen to analyze the morphology of the electrodeposited films. X-ray diffraction (XRD) was used to analyze the crystal structure of the films. The corrosion resistance and hardness of the nanocomposite films were compared with each bath condition using Tafel polarization, immersion tests, and nanoindentation. The $\mathrm{pH}$ of the plating solution was varied by adding different amounts of sodium citrate and citric acid. The citrate ligand was used to stabilize nickel ions in the plating solution. Viscosity, conductivity, zeta potential, and particle size were all measured for the addition of montmorillonite to the plating solution.

\section{Experimental}

2.1. Materials. Nickel-layered silicates were electrochemically deposited from acidic plating baths at $\mathrm{pH} 1.6,2.5$, and 3.0 at $25^{\circ} \mathrm{C}$. The montmorillonite (MMT) $(5 \mathrm{~g} / \mathrm{L})$ aqueous solution from Southern Clay Products was mechanically agitated using a magnetic stirrer over 24 hours to obtain exfoliated layered silicate platelets. Citric acid anhydrous and/or sodium citrate dihydrate was utilized as a ligand to stabilize nickel (II) ions. The composition of nickel-citrate plating baths at different $\mathrm{pHs}$ was prepared from $\mathrm{NiSO}_{4} \cdot 6 \mathrm{H}_{2} \mathrm{O}$ (Alfa Aesar) and $\mathrm{Na}_{3} \mathrm{C}_{6} \mathrm{H}_{5} \mathrm{O}_{7} \cdot 6 \mathrm{H}_{2} \mathrm{O}$ (Fisher Scientific) or $\mathrm{H}_{3} \mathrm{C}_{6} \mathrm{H}_{5} \mathrm{O}_{7}$ (Fisher Scientific) as shown in Table 1.

The exfoliated MMT solution was added to the nickel and citrate salts and then stirred with a magnetic stirrer until dissolved. The $\mathrm{pH}$ of the plating solution was measured with a Corning $\mathrm{pH}$ meter and Pasco Scientific $\mathrm{pH}$ electrode. The electrochemical cell was comprised of three electrodes: chromel wire (counter electrode), saturated calomel (reference electrode), and stainless steel discs (working electrode). Stainless steel discs with a diameter of $1 \mathrm{~cm}^{2}$ were polished mechanically with 600, 800, and 1000 grit silicon carbide paper and then with 3 and $1 \mu \mathrm{m}$ diamond solution on felt cloth. After the electrode was polished to a mirror-like finish, it was sonicated in deionized water for 10 minutes.

2.2. Electrodeposition. An EG\&G PAR Potentiostat/Galvanostat Model 273A was used for all depositions, cyclic voltammetry, and corrosion studies. Pulsed electrodeposition of the film was carried out using a potential of $-1.1 \mathrm{~V}$ for 10 seconds then steped to $-0.58 \mathrm{~V}$ for 3 seconds until a total charge of $70 \mathrm{C}$.
TABLE 1: Values of the acidic plating bath composition for nickel, citrate, and citric acid.

\begin{tabular}{lccc}
\hline Chemical & pH 1.6 & pH 2.5 & pH 3.0 \\
\hline $\mathrm{NiSO}_{4} \cdot 6 \mathrm{H}_{2} \mathrm{O}$ & $77.8 \mathrm{~g} / \mathrm{L}$ & $77.8 \mathrm{~g} / \mathrm{L}$ & $77.8 \mathrm{~g} / \mathrm{L}$ \\
$\mathrm{Na}_{3} \mathrm{C}_{6} \mathrm{H}_{5} \mathrm{O}_{7} \cdot 6 \mathrm{H}_{2} \mathrm{O}$ & - & $35.3 \mathrm{~g} / \mathrm{L}$ & $52.9 \mathrm{~g} / \mathrm{L}$ \\
$\mathrm{H}_{3} \mathrm{C}_{6} \mathrm{H}_{5} \mathrm{O}_{7}$ & $57.6 \mathrm{~g} / \mathrm{L}$ & $34.6 \mathrm{~g} / \mathrm{L}$ & $23.0 \mathrm{~g} / \mathrm{L}$ \\
\hline
\end{tabular}

2.3. Solution Studies. The solutions prepared for measurement of kinematic viscosity, zeta potential, particle size, and conductivity consisted of the exfoliated MMT solutions and the nickel-citrate plating solution. The zeta potential of the various plating solutions were measured using a Delsa NanoC (Beckman-Coulter Instruments). The size of the particles in the solution was determined by photon correlation spectroscopy using the Delsa Nano-C. The samples were allowed to equilibrate at $25^{\circ} \mathrm{C}$ for 60 seconds using a peltier device in the instrument. The samples were measured for zeta potential three times to show reproducibility of the measurement. Kinematic viscosity (cSt) was measured with a Cannon Ubbelohde viscometer size 50 . The viscometer with $20 \mathrm{~mL}$ of sample was placed into a Brinkmann RM6 water bath at $25^{\circ} \mathrm{C}$ and allowed to equilibrate for 20 minutes. The flow time was measured in seconds and multiplied by the kinematic viscosity constant $(\mathrm{cSt} / \mathrm{s})$. Each sample was measured five times to show reproducibility of the kinematic viscosity measurement. The conductivity was measured with a Thermo Orion 550 A conductivity meter.

2.4. Characterization Techniques. The surface morphology of the films was characterized with an Environmental FEI Quanta 200 scanning electron microscope (SEM). X-ray diffraction data was obtained on a Siemens D-500 Diffractometer using $\mathrm{Cu} \mathrm{K} \alpha$ radiation $(\lambda=0.1541 \mathrm{~nm})$ at $35 \mathrm{kV}$ and $24 \mathrm{~mA}$. The scans were run from $2-100^{\circ} 2 \theta$ at a step size of 0.05 degrees and dwell time of 1 second.

2.5. Corrosion Measurements. Corrosion behavior was studied by electrochemical techniques. A four-electrode electrochemical cell was used as a corrosion testing system composed of the working electrode of the nanocomposite film, two graphite rods, and a saturated calomel electrode (SCE). Tafel plots were acquired in a 3.5\% sodium chloride solution. A $\pm 100 \mathrm{mV}$ potential range was applied to the cell without stirring the solution; the resulting current density was then measured. In each scan, the run started at open circuit potential $E_{\text {ocp }}$ with a scan rate of $1 \mathrm{mV} / \mathrm{s}$. Both cathodic and anodic scans were recorded starting from OCP. The nickel-layered silicate films were also immersed in a 3.5\% sodium chloride solution for extended periods (30 days) while monitoring OCP.

\section{Results and Discussion}

3.1. Kinematic Viscosity. The layered silicate was stirred over 24 hours resulting in exfoliated montmorillonite (MMT) platelets. A certain amount of anionic exfoliated MMT was 


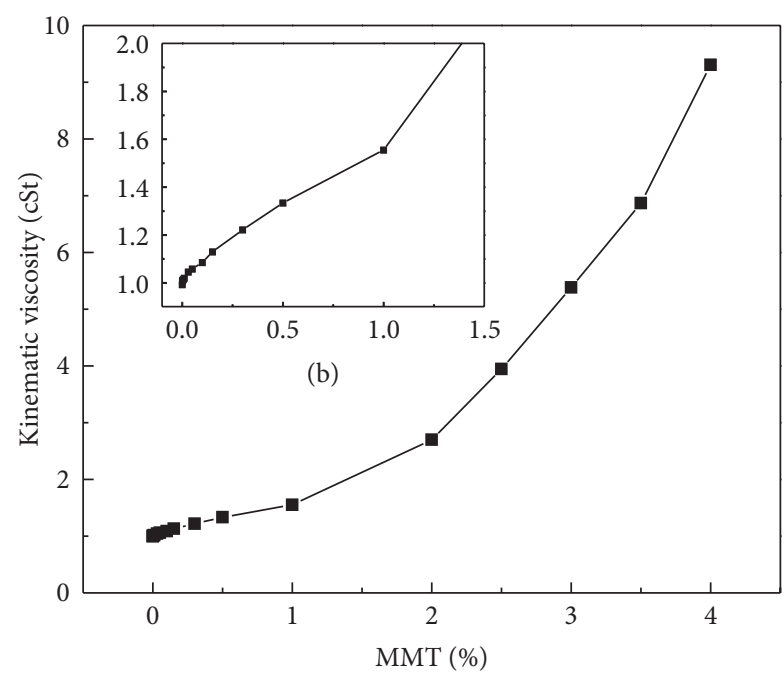

(a)

FIGURE 1: Kinematic viscosity of montmorillonite (MMT) solutions.

able to suspend in the aqueous solution forming an equilibrium of the individual particle repulsions. If the MMT concentration is too high, agglomeration and precipitation occur, resulting in an increase of viscosity. The optimum amount of MMT is chosen from viscosity based on the kinematic viscosity curve (Figure 1). The exfoliated MMT are nonspherical particles; thus, the rotary Brownian motion may lead to non-Newtonian effect even in the diluted solution. The addition of more MMT particles changes the magnitude of the kinematic viscosity because of its platelet shape and charged surface, which results in a deviation of Newtonian behavior [22]. According to Figure 1(b), the viscosity of the MMT solution gradually increases until $0.5 \%$ MMT. Then the viscosity starts to dramatically increase when MMT is higher than $1 \%$ as seen from the steep increase of the slope. The viscosity increase is linear at very low concentration ranges. The kinematic viscosity values for the concentrations of $0.5 \%$ MMT was $1.33 \mathrm{cSt}$ at $25^{\circ} \mathrm{C}$. The MMT concentration of $0.5 \%$ is selected to be used in the nickel plating solution because the viscosity stays stable at about this concentration. When introducing an exfoliated MMT into the nickel solution, it becomes a thickened fluid because the opposite charge of nickel ion is electrostatically adsorbed onto the clay surface (negative-charged) leading to agglomeration of the particles. Once citrate ions are added into the nickel-MMT solution, the viscosity decreases because citrate ligands help stabilize nickel ions in the solution. However, the viscosity of $\mathrm{Ni}$-citrate in MMT solution is still higher than that of only Ni-citrate solution because free nickel cations are able to be adsorbed onto the MMT surface.

3.2. Zeta Potential and Particle Size. As shown previously, typically the surface forces can be the key factor for incorporation of particles into a metal matrix during electrodeposition [23]. The zeta potential of layered silicate nanoparticles were measured at three different $\mathrm{pHs}(1.6,2.5$, and 3.0).

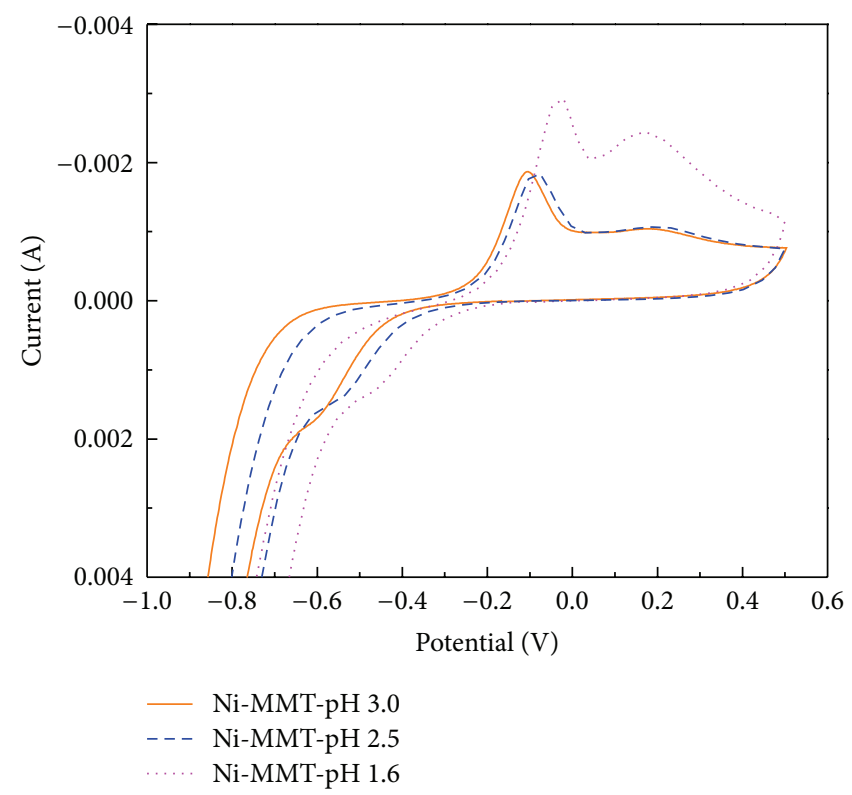

FIGURE 2: Cyclic voltammograms of nickel-layered silicate $(0.5 \%$ MMT) plating solution for various $\mathrm{pHs}(1.6,2.5,3.0)$.

TABLE 2: Plating solution measurements of conductivity, viscosity, zeta potential, and particle size for various $\mathrm{pHs}(1.6,2.5,3.0)$ of the plating bath.

\begin{tabular}{lcccc}
\hline $\begin{array}{l}\text { Plating } \\
\text { solution } \\
\text { pH }\end{array}$ & $\begin{array}{c}\text { Conductivity } \\
(n=3) \\
(\mathrm{mS} / \mathrm{cm})\end{array}$ & $\begin{array}{c}\text { Viscosity } \\
(n=3) \\
(\mathrm{cSt})\end{array}$ & $\begin{array}{c}\text { Particle } \\
\text { size } \\
(\mathrm{nm})\end{array}$ & $\begin{array}{c}\text { Zeta potential } \\
(n=3) \\
(\mathrm{mV})\end{array}$ \\
\hline $\mathrm{pH} 1.6$ & $24.3 \pm 0.1$ & $2.86 \pm 0.03$ & 3120 & $-10.1 \pm 0.3$ \\
$\mathrm{pH} 2.5$ & $28.1 \pm 0.2$ & $2.64 \pm 0.01$ & 2756 & $-22.2 \pm 0.9$ \\
pH 3.0 & $33.7 \pm 0.3$ & $2.21 \pm 0.01$ & 2517 & $-21.9 \pm 0.4$ \\
$0.5 \%$ & $0.502 \pm 0.008$ & $1.33 \pm 0.01$ & 591 & $-43.2 \pm 0.8$ \\
MMT & & & & \\
\hline
\end{tabular}

In order to investigate the influence of the bath composition and $\mathrm{pH}$, the zeta potential of each condition was analyzed for particle stability (Table 2). The zeta potential of the charged particles helps predict colloidal stability and electrostatic interaction of the particles. The zeta potential represents the repulsive forces between particles. Because most aqueous colloidal systems are stabilized by electrostatic repulsion, the larger repulsive forces between particles result in the particles being stabilized in solution, which reduces the possibility for the particles to aggregate. The exfoliated MMT is known to have a negative charge on its surface [24]. The exfoliated MMT (0.5\%) solution has a zeta potential of $-43.2 \mathrm{mV}$. It is stable and able to suspend in the aqueous solution while the nonexfoliated MMT precipitates. Based on the results from the zeta-potential analysis of the nickel-citrate-MMT plating solution, $\mathrm{pH} 2.5(-22.2 \mathrm{mV})$ and $\mathrm{pH} 3.0(-21.9 \mathrm{mV})$ solutions are more stable than $\mathrm{pH} 1.6(-10.1 \mathrm{mV})$ solution (Table 2). The adsorption of the nickel and citrate at the MMT surface shifted the zeta potential toward positive values dropping the electrostatic stabilization of the dispersion. However, the particles at $\mathrm{pH} 2.5$, and $\mathrm{pH} 3.0$ are much more stable than that 


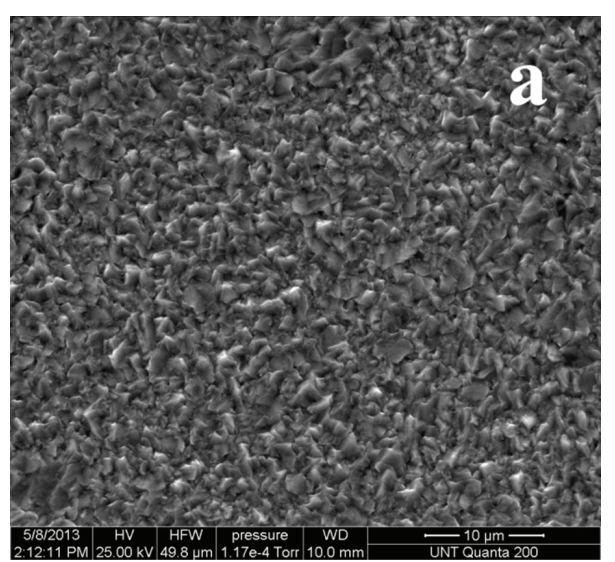

(a)

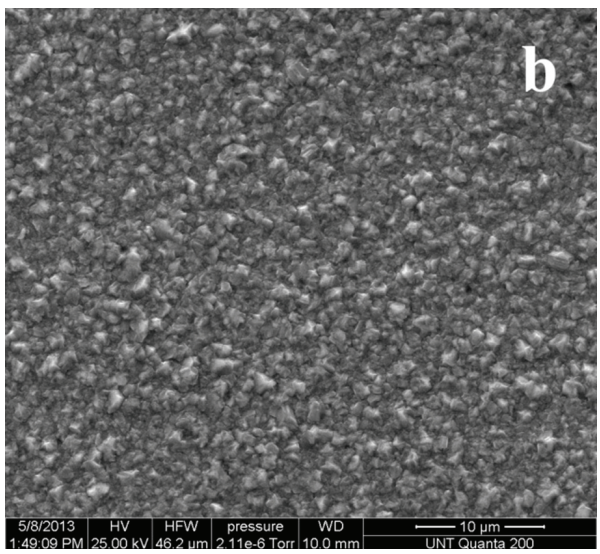

(b)

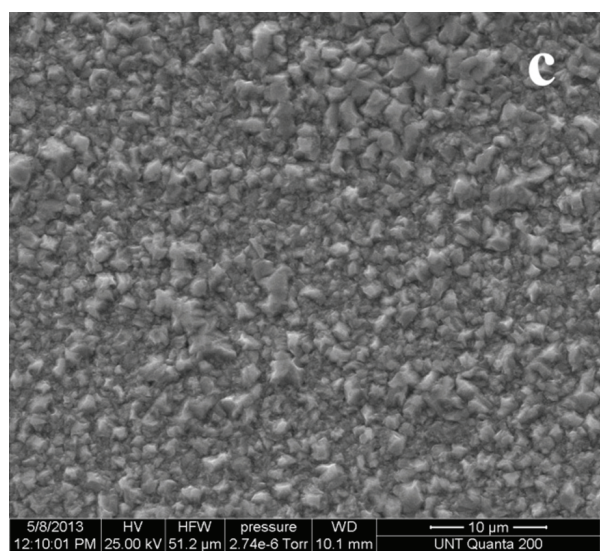

(c)

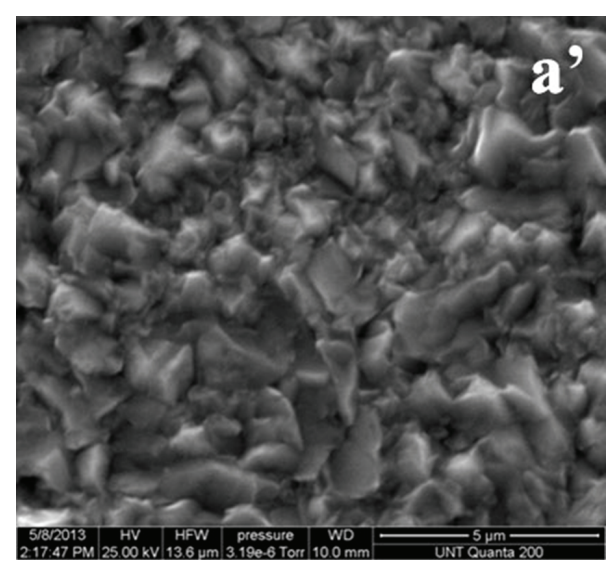

$\left(a^{\prime}\right)$

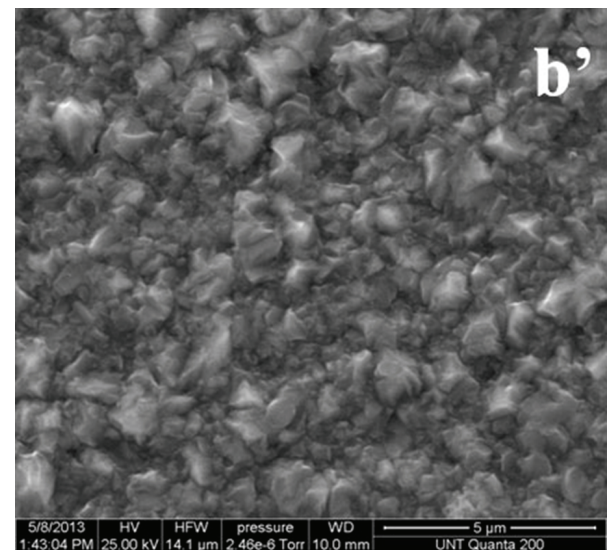

$\left(b^{\prime}\right)$

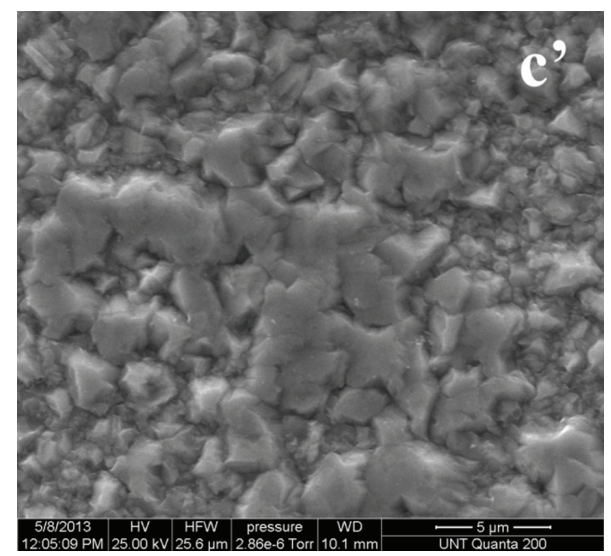

$\left(c^{\prime}\right)$

FIGURE 3: Scanning electron microscopy (SEM) images of Ni-MMT (0.5\%) films electrodeposited from plating baths at pHs $1.6\left((\mathrm{a})\right.$ and $\left.\left(\mathrm{a}^{\prime}\right)\right)$, $2.5\left((\mathrm{~b})\right.$ and $\left.\left(\mathrm{b}^{\prime}\right)\right)$, and $3.0\left((\mathrm{c})\right.$ and $\left.\left(\mathrm{c}^{\prime}\right)\right)$.

at $\mathrm{pH}$ 1.6. This was also confirmed by allowing the solution to sit stagnant for 24 hours in which time the $\mathrm{pH} 1.6$ solution precipitated out, whereas the $\mathrm{pH} 2.5$ and 3.0 stayed stable in solution for 3-4 more days.

In addition, the particle's size decreased as $\mathrm{pH}$ increased with changing citrate concentration (Table 2). The particle size of $0.5 \%$ MMT in water is $591 \mathrm{~nm}$. When the MMT concentration is introduced to the nickel plating bath, the particle size becomes larger than the native MMT particles. A slight change was observed from 3120 to $2517 \mathrm{~nm}$ as the $\mathrm{pH}$ increased, which follows the decrease in viscosity as $\mathrm{pH}$ increases (Table 2). At $\mathrm{pH} 1.6$, mostly free $\mathrm{Ni}^{2+}$ ions are present to adsorb to the surface of the MMT, whereas at the higher $\mathrm{pH}$ values of 2.5 and 3.0 a nickel-citrate complex (NiHCit) is formed removing some of the free $\mathrm{Ni}^{2+}$ ions that could bind to MMT [25]. This follows the result where the 


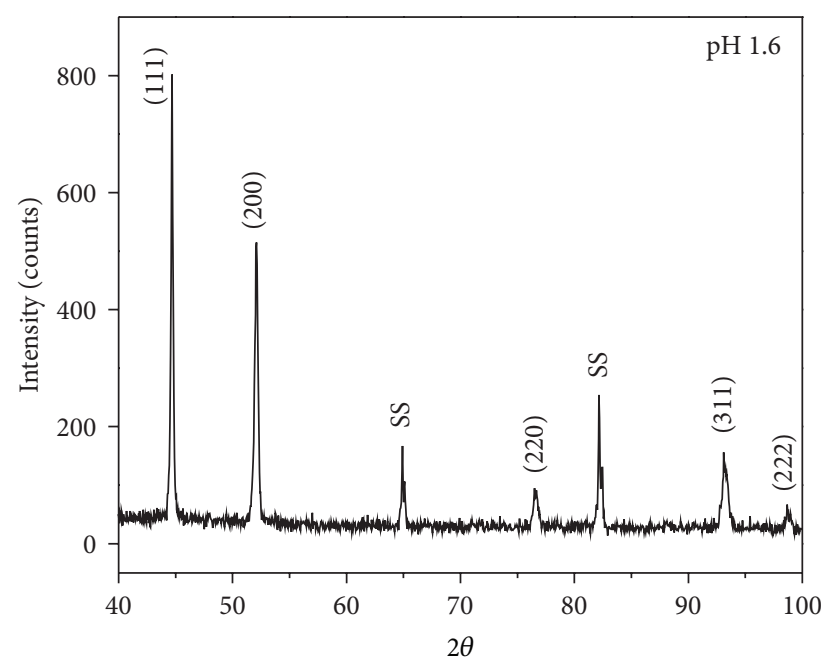

(a)

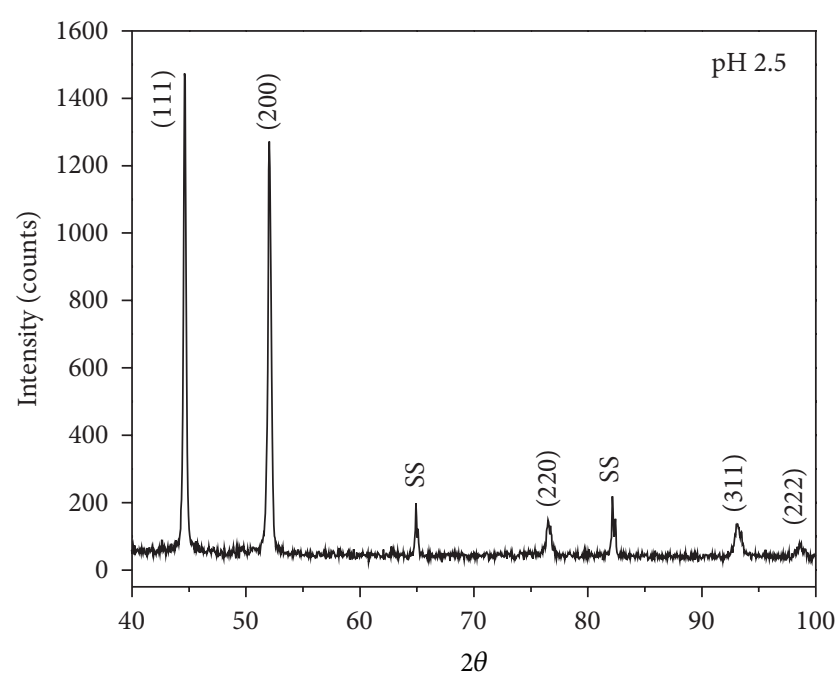

(b)

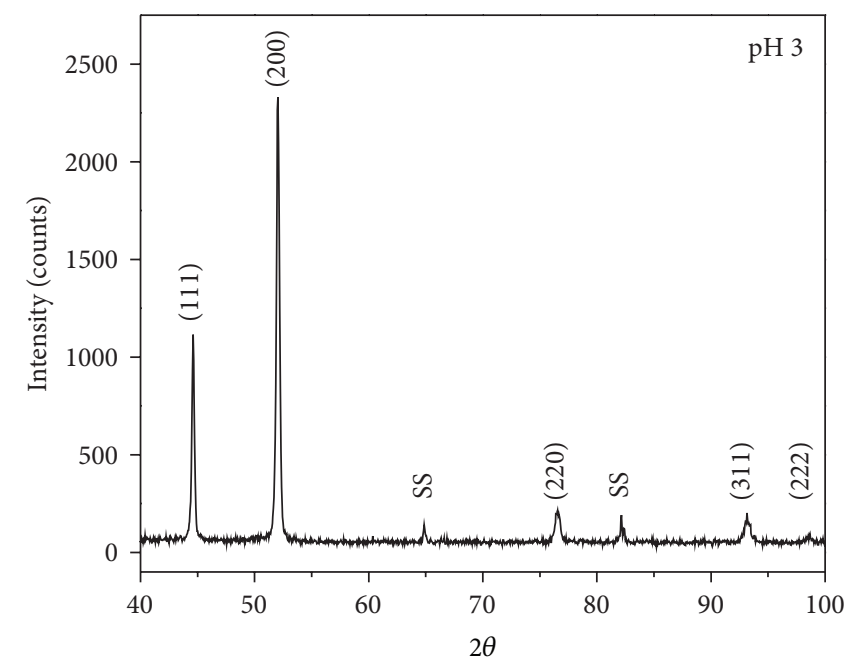

(c)

FIGURE 4: X-ray diffraction (XRD) patterns of Ni-MMT (0.5\%) films electrodeposited at various pHs (a) 1.6, (b) 2.5 and (c) 3.0 (SS: substrate stainless steel peaks).

particle size and viscosity decrease as the $\mathrm{pH}$ is increased from 1.6 to 3.0 .

3.3. Cyclic Voltammetry. Cyclic voltammetry (CV) was run for the nickel-layer silicate plating solutions at $\mathrm{pHs}$ of 1.6, 2.5, and 3.0 and shown in Figure 2. The $\mathrm{pH}$ influences the electrodeposition of Ni-MMT. The reduction peak for NiMMT at $\mathrm{pH} 3.0$ is shifted to a more negative potential $(-0.6 \mathrm{~V})$. Also the working window of the electrodeposition was expanded at $\mathrm{pH} 3.0$, pushing the hydrogen evolution further cathodic and resulting in smoother films (Figure 2) [26]. The nickel-citrate species varied with respect to $\mathrm{pH}$ values [26]. For a nickel-citrate bath at $\mathrm{pH}$ less than 4 , the predominant species is NiCitH with trace amount of $\mathrm{NiH}_{2} \mathrm{Cit}^{+}$ (less than 2\%). At pH lower than 2, most of the nickel exists as free nickel ions; as the $\mathrm{pH}$ increases from 2 to 3 , the nickel-citrate species are mostly represented as $\mathrm{NiCitH}$ and
$\mathrm{NiH}_{2} \mathrm{Cit}^{+}$, with less free nickel ions [26-28]. MMT improves adhesion and provides for a smoother film because the nonelectroactive platelets slow down the reduction reaction and push hydrogen evolution more cathodic (as seen in cyclic voltammetry). Also the nickel films without MMT at these $\mathrm{pHs}$ tended to have poor adhesion. The $\mathrm{pH} 3$ nanocomposite film was the optimal coating giving the best results of overall properties for adhesion, corrosion protection and mechanical properties.

3.4. Film Characterization. The $\mathrm{pH}$ also affects nickel crystalline growth as shown by SEM (Figure 3) and XRD (Figure 4). At very low $\mathrm{pH}$ there is more hydrogen formation and the plating rate is faster resulting in a non-uniform film and larger grain size. At $\mathrm{pH}$ of 2.5 and 3.0 the rate of electrodeposition is slower and hydrogen evolution decreases resulting in smoother uniform films and longer deposition 
TABLE 3: Nanoindentation hardness and young modulus of the NiMMT (0.5\%) nanocomposite films electrodeposited at various $\mathrm{pHs}$ $(1.6,2.5,3.0)$.

\begin{tabular}{lcc}
\hline $\begin{array}{l}\text { Ni-MMT } \\
\text { coatings pHs }\end{array}$ & $\begin{array}{c}\text { Young modulus } \\
(\mathrm{GPa} \pm \mathrm{SD}, n=25)\end{array}$ & $\begin{array}{c}\text { Nanoindentation hardness } \\
(\mathrm{GPa} \pm \mathrm{SD}, n=25)\end{array}$ \\
\hline $\mathrm{pH} 1.6$ & $147 \pm 50$ & $4.1 \pm 1.5$ \\
$\mathrm{pH} 2.5$ & $174 \pm 52$ & $3.3 \pm 1.2$ \\
$\mathrm{pH} 3.0$ & $234 \pm 57$ & $5.3 \pm 1.6$ \\
\hline
\end{tabular}

time for the same accumulated charges. Pulse electrodeposition is applied for depositing the nickel-MMT films at low $\mathrm{pH}$ (1.6-3.0). Through experiments, it was determined that the electrodeposition of nickel at $\mathrm{pH}$ values greater than 3.5 tended to have poor adhesion that required other pretreatment of the stainless steel substrate or a different plating bath for adhesion of the coating. By pulsing, there is an increase in the replenishment of nickel cations in the diffusion layer and diffusion of hydrogen away from the electrode surface $[7,29]$. Also, the pulse deposition method provided a uniform, smooth film with good adhesion. A direct potential method was attempted but it was found that the films deposited in a non-uniform manner and had poor adhesion. SEM micrographs of the deposits show microstructures with grain sizes in the micrometer range. However, it is clear from Figure 3 that at $\mathrm{pH} 3.0$ there is a progressive change in the crystal orientation from an almost random texture to a stronger (200) texture. This may be due to the stronger nickel-citrate chelate $\mathrm{NiHCit}$ formation at $\mathrm{pH}$ 3.0, which stabilizes the nickel in solution and allows for slower dissolution at the electrode surface. This truncation of the pyramidal grains (observed for $\mathrm{pH} 1.6$ and 2.5) occurs for pH 3.0 (Figure 3) which would support the enhanced (200) texture of the $\mathrm{pH} 3.0$ deposits.

The Ni-MMT films fabricated at $\mathrm{pH} 1.6$ are crystalline and give a random XRD pattern that matches the PDF no. 00004-0850 for nickel (Figure 4). When $\mathrm{pH}$ of the plating bath is increased to 2.5 and 3.0, Ni-MMT films start to show an orientation preference for (200) growth. An electrostatic stabilization of dispersion of the nickel-citrate-MMT particles benefits insertion of MMT into the nickel electrodeposited films. The nanoindentation results also support that the hardness is highest for coatings deposited at pH $3.0(234 \mathrm{GPa})$ over that of coatings deposited at pH 1.6 and 2.5 (Table 3).

3.5. Corrosion Studies. The electrochemical corrosion parameters from the Tafel data (Figure 5) are summarized in Table $4 . R_{p}$ is the polarization resistance experimentally observed between the applied electrochemical current density and potential for the corroding electrode within a few millivolts of the polarization from the corrosion potential $\left(E_{\text {corr }}\right)$. The corrosion current density $\left(i_{\text {corr }}\right)$ is approximately calculated from a simplified rearranged Stern and Geary equation with respect to the two anodic and cathodic Tafel slopes. The corrosion rate is inversely proportional to the polarization resistance. However, the film fabricated from pH 3 exhibited a passive region (plateau region) with a higher anodic potential of the polarization (Figure 5). The

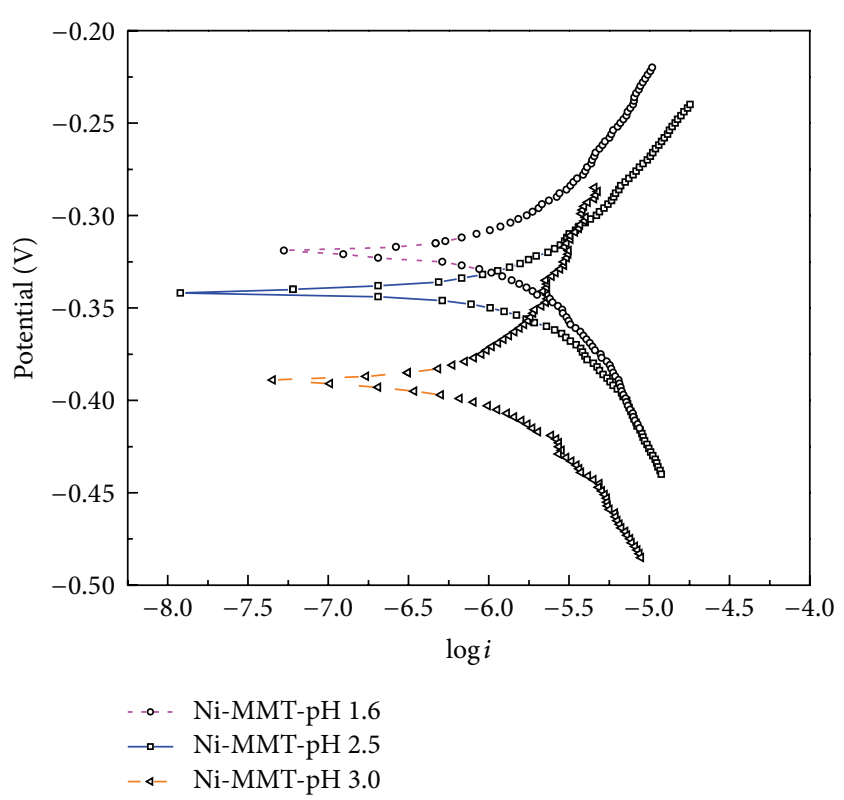

Figure 5: Tafel plot of Ni-MMT (0.5\%) films measured in 3.5\% $\mathrm{NaCl}$ solution at $25^{\circ} \mathrm{C}$. Coatings were electrodeposited from a plating solution at various $\mathrm{pHs}(1.6,2.5$, and 3.0$)$ onto stainless steel substrates.

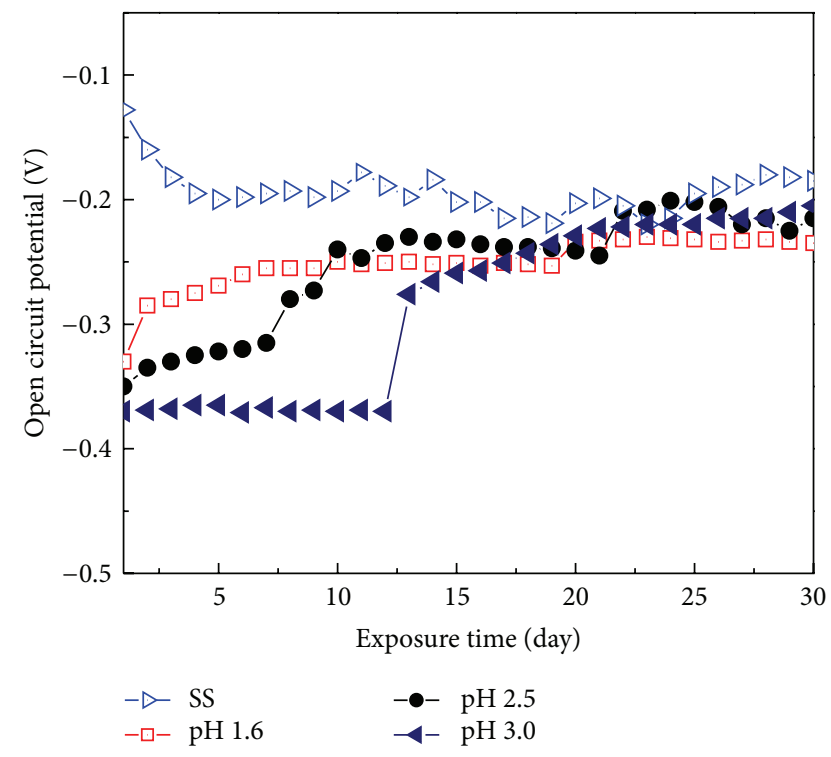

FIgURE 6: Open circuit potential (OCP) versus immersion time in $3.5 \% \mathrm{NaCl}$ for nickel-layered silicate films electrodeposited from various pHs $(1.6,2.5,3.0)$. Values are an average of three runs with a standard deviation of \pm 0.02 .

corrosion parameters, $\left(R_{p}, E_{\text {corr }}\right.$, and $\left.i_{\text {corr }}\right)$, are all within the same range for $\mathrm{pH} 1.6,2.5$, and 3.0 (Table 4). The corrosion potential of the films decreases from $-0.32,-0.34$, and $-0.39 \mathrm{~V}$ for different $\mathrm{pHs}$ of $1.6,2.5$, and 3.0 , respectively, while the corrosion rate improves for the $\mathrm{pH} 3.0$ coating. The immersion corrosion tests were conducted at ambient temperature to monitor OCP values for one month (Figure 6). The films deposited at $\mathrm{pH} 3$ show the greatest improvement 


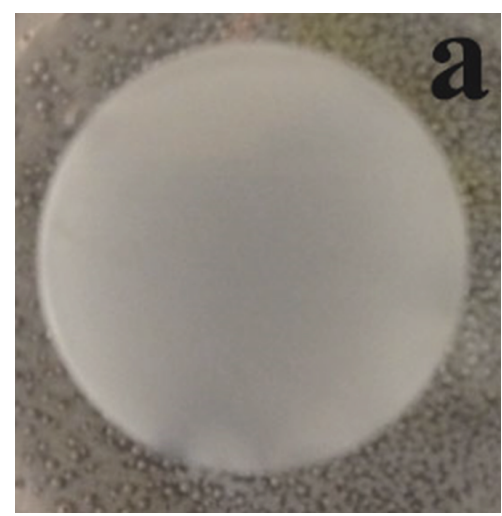

(a)

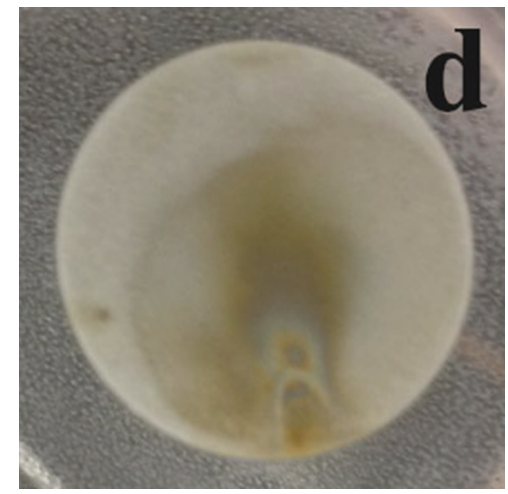

(d)

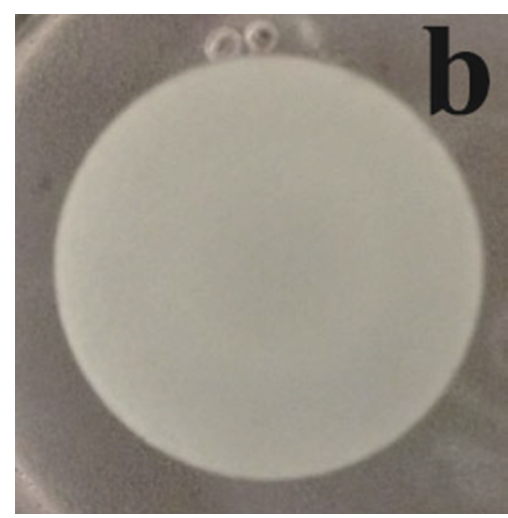

(b)

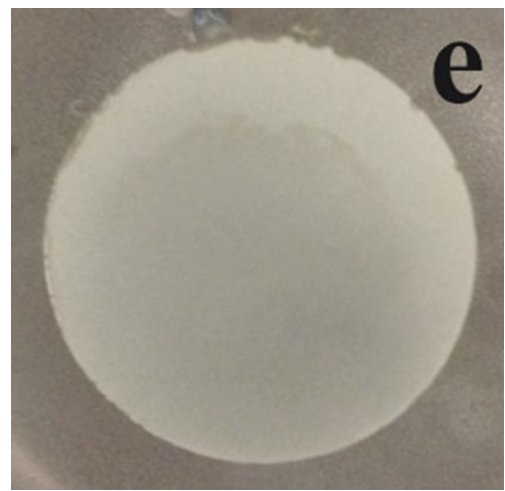

(e)

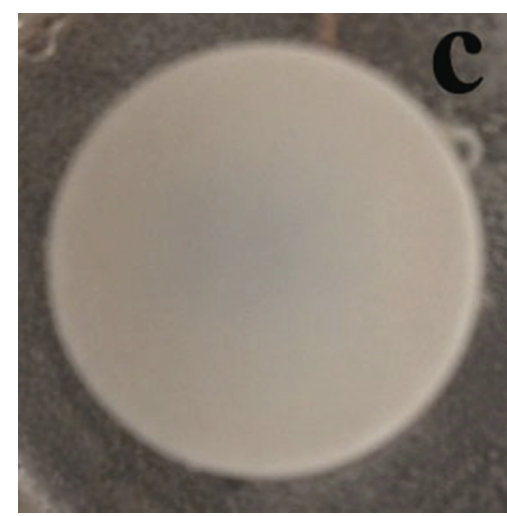

(c)

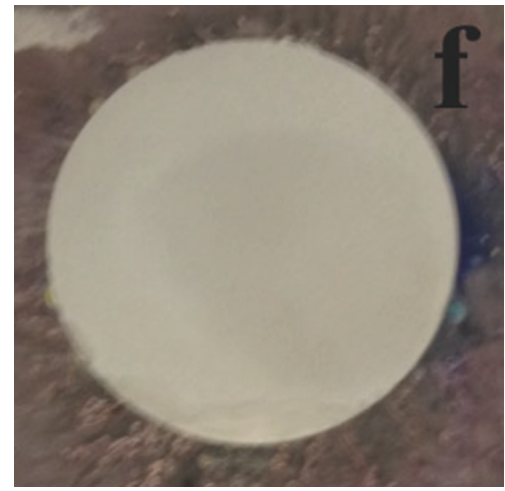

(f)

FIGURE 7: Sample images of Ni-MMT coatings electrodeposited from plating baths at various pHs of 1.6, 2.5, and 3.0 before immersion in $3.5 \% \mathrm{NaCl}(\mathrm{a})-(\mathrm{c})$, and after (d)-(f), respectively.

in corrosion protection taking 13 days to reach the OCP of the stainless steel. The coatings deposited at $\mathrm{pH} 1.6$ began to corrode within a day based on the immersion OCP values matching stainless steel. The immersion test was run three times for each of the $\mathrm{pHs}$ and the average was taken to create Figure 6 with an overall standard deviation of \pm 0.02 . Figure 7 shows the coatings at $\mathrm{pH} 1.6,2.5$, and 3.0 before and after 30 days of immersion in $3.5 \% \mathrm{NaCl}$. At $\mathrm{pH} \mathrm{1.6}$, corrosion is visible for the coating (Figure 7(d)), whereas pH 2.5 just starts to show corrosion effects at the edges of the substrate (Figure 7(e)). The coating at pH 3.0 still shows no visible corrosion at 30 days and is the most stable of the coatings.

\section{Conclusion}

The optimal bath composition was developed to improve film adhesion to stainless steel, corrosion protection, and mechanical properties. To obtain the stable layered silicate particles for the codeposition with nickel, the viscosity, conductivity, zetapotential, and particle size were analyzed. The particles at $\mathrm{pH} 2.5(-22.2 \mathrm{mV})$ and $\mathrm{pH} 3.0(-21.9 \mathrm{mV})$ were more stable than that at $\mathrm{pH} 1.6(-10.1 \mathrm{mV})$. Corrosion was investigated by Tafel polarization and open circuit potential measurement versus time. XRD determined that the $(111) /(200)$ ratio changed with deposition $\mathrm{pH}$. The SEM and hardness results
TABLE 4: $E_{\text {corr }}, i_{\text {corr }}$ and polarization resistance (Rp) of the Ni-MMT $(0.5 \%)$ nanocomposite film electrodeposited at various $\mathrm{pHs}(1.6,2.5$, 3.0) of the plating bath.

\begin{tabular}{lccc}
\hline $\begin{array}{l}\text { Ni-MMT } \\
\begin{array}{l}\text { coating } \\
\text { deposited at }\end{array}\end{array}$ & $\begin{array}{c}E_{\text {corr }}(\mathrm{V}) \\
\mathrm{SD}(n=3)\end{array}$ & $\begin{array}{c}i_{\text {corr }}\left(\mathrm{A} \cdot \mathrm{cm}^{-2}\right) \\
\pm \mathrm{SD}(n=3)\end{array}$ & $\begin{array}{c}\mathrm{Rp}\left(\Omega \cdot \mathrm{cm}^{2}\right) \\
\pm \mathrm{SD}(n=3)\end{array}$ \\
\hline pH 1.6 & $-0.32 \pm 0.02$ & $9.02 \pm 3 \times 10^{-7}$ & $1.47 \pm 0.5 \times 10^{5}$ \\
pH 2.5 & $-0.34 \pm 0.02$ & $9.48 \pm 3 \times 10^{-7}$ & $1.84 \pm 0.4 \times 10^{5}$ \\
pH 3.0 & $-0.39 \pm 0.02$ & $7.34 \pm 2 \times 10^{-7}$ & $1.16 \pm 0.2 \times 10^{5}$ \\
\hline
\end{tabular}

also supported that the nickel-MMT nanocomposites at $\mathrm{pH}$ $2.5(174 \mathrm{GPa})$ and $3.0(234 \mathrm{GPa})$ were better than at $\mathrm{pH} 1.6$ $(147 \mathrm{GPa})$. From all the combined data, the $\mathrm{pH} 3.0$ coating with incorporated MMT gave the best adherence, hardness, and corrosion protection for the nanocomposite coatings.

\section{Acknowledgment}

This work was made possible by NPRP Grant 4-306-2-111 from the Qatar National Research Fund (a Member of The Qatar Foundation). The statements made herein are solely the responsibility of the authors. 


\section{References}

[1] W. Z. Friend, Corrosion of Nickel and Nickel-Base Alloys, WilleyInterscience, New York, NY, USA, 1980.

[2] Y.-Y. Chang and D.-Y. Wang, "Corrosion behavior of electroless nickel-coated AISI 304 stainless steel enhanced by titanium ion implantation," Surface and Coatings Technology, vol. 200, no. 7, pp. 2187-2191, 2005.

[3] L. Wang, J. Zhang, Y. Gao, Q. Xue, L. Hu, and T. Xu, “Grain size effect in corrosion behavior of electrodeposited nanocrystalline Ni coatings in alkaline solution," Scripta Materialia, vol. 55, no. 7, pp. 657-660, 2006.

[4] Y. Xuetao, W. Yu, S. Dongbai, and Y. Hongying, "Influence of pulse parameters on the microstructure and microhardness of nickel electrodeposits," Surface and Coatings Technology, vol. 202, no. 9, pp. 1895-1903, 2008.

[5] D. Brondel, R. Edwards, A. Hayman, D. Hill, S. Mehta, and T. Semerad, "Corrosion in the oil industry," Oilfield Review, vol. 6, no. 2, pp. 4-18, 1994.

[6] R. A. Horch, T. D. Golden, N. A. D'Souza, and L. Riester, "Electrodeposition of nickel/montmorillonite layered silicate nanocomposite thin films," Chemistry of Materials, vol. 14, no. 8, pp. 3531-3538, 2002.

[7] H. A. Conrad, J. R. Corbett, and T. D. Golden, "Electrochemical deposition of $\gamma$-phase zinc-nickel alloys from alkaline solution," Journal of the Electrochemical Society, vol. 159, no. 1, pp. C29C32, 2012.

[8] V. DeLeon and T. D. Golden, "Effect of electrochemical parameters on the morphology and $\mathrm{Ca} / \mathrm{P}$ ratios of deposited apatite coatings on metal and alloy substrates," ECS Transitions, vol. 33, no. 21, pp. 43-50, 2011.

[9] P. H. C. Camargo, K. G. Satyanarayana, and F. Wypych, "Nanocomposites: synthesis, structure, properties and new application opportunities," Materials Research, vol. 12, no. 1, pp. 1-39, 2009.

[10] W. Chen, Y. He, and W. Gao, "Synthesis of nanostructured $\mathrm{Ni}-\mathrm{TiO}_{2}$ composite coatings by sol-enhanced electroplating," Journal of the Electrochemical Society, vol. 157, no. 8, pp. E122E128, 2010.

[11] L. Benea, "Electrodeposition and tribocorrosion behaviour of $\mathrm{ZrO}_{2}$-Ni composite coatings," Journal of Applied Electrochemistry, vol. 39, no. 10, pp. 1671-1681, 2009.

[12] I. Corni, R. J. Chater, A. R. Boccaccini, and M. P. Ryan, "Electro co-deposition of $\mathrm{Ni}-\mathrm{Al}_{2} \mathrm{O}_{3}$ composite coatings," Journal of Materials Science, vol. 47, p. 561, 2012.

[13] H. B. Temam, I. Zeroual, A. Chala, S. Rahmane, and C. Nouveau, "Microhardness and corrosion behavior of Ni-SiC electrodeposited coatings," Plasma Processes and Polymers, vol. 4, no. 1, pp. S618-S621, 2007.

[14] R. Sen, S. Das, and K. Das, "Influence of duty cycle on the microstructure and microhardness of pulse electrodeposited $\mathrm{Ni}-\mathrm{CeO}_{2}$ nanocomposite coating," Materials Research Bulletin, vol. 47, no. 2, pp. 478-485, 2012.

[15] L. Sahu and N. A. D’Souza, "Interfacial effects in montmorillonite filled polyester thin films," Open Macromolecules Journal, vol. 6, pp. 28-32, 2012.

[16] E. Ogunsona, S. Ogbomo, M. Nar, and N. A. D’Souza, “Thermal and mechanical effects in polystyrene-montmorillonite nanocomposite foams," Cellular Polymers, vol. 30, no. 2, pp. 7994, 2011.
[17] M. C. Richardson, J. Kim, D. Ho, C. R. Snyder, N. A. D'Souza, and G. A. Holmes, "Organofunctionalized montmorillonite/epoxy nanocomposites: the effect of interlayer cation distribution on mechanical properties," Polymer Composites, vol. 32, no. 1, pp. 67-78, 2011.

[18] A. Q. Wang, N. A. D'Souza, and T. D. Golden, "Ceramic montmorillonite nanocomposites by electrochemical synthesis," Applied Clay Science, vol. 42, no. 1-2, pp. 310-317, 2008.

[19] A. Q. Wang, N. A. D'Souza, and T. D. Golden, "Electrosynthesis of nanocrystalline cerium oxide/layered silicate powders," Journal of Materials Chemistry, vol. 16, no. 5, pp. 481-488, 2006.

[20] D. Zaarei, A. A. Sarabi, F. Sharif, and S. M. Kassiriha, "Structure, properties and corrosion resistivity of polymeric nanocomposite coatings based on layered silicates," Journal of Coatings Technology Research, vol. 5, no. 2, pp. 241-249, 2008.

[21] A. Olad, M. Amini, and A. Rashidzadeh, "Electrodeposition of homogeneous and adherent polypyrrole/ $\mathrm{Na}^{+}$-cloisite nanocomposite on iron electrodes," Fibers and Polymers, vol. 13, no. 4, pp. 475-480, 2012.

[22] C. W. Macosko, Rheology: Principles, Measurements and Applications, John Wiley \& Sons, New York, NY, USA, 1993.

[23] C. Dedeloudis, J. Fransaer, and J.-P. Celis, "Surface force measurements at a copper electrode/electrolyte interface," Journal of Physical Chemistry B, vol. 104, no. 9, pp. 2060-2066, 2000.

[24] A. M. L. Kraepiel, K. Keller, and F. M. M. Morel, "A model for metal adsorption on montmorillonite," Journal of Colloid and Interface Science, vol. 210, no. 1, pp. 43-54, 1999.

[25] T. A. Green, A. E. Russell, and S. Roy, "The development of a stable citrate electrolyte for the electrodeposition of coppernickel alloys," Journal of the Electrochemical Society, vol. 145, no. 3, pp. 875-881, 1998.

[26] C.-Q. Li, X.-H. Li, Z.-X. Wang, and H.-J. Guo, "Nickel electrodeposition from novel citrate bath," Transactions of Nonferrous Metals Society of China, vol. 17, no. 6, pp. 1300-1306, 2007.

[27] O. Y. Zelenin, "Interaction of the $\mathrm{Ni}^{2+}$ ion with citric acid in an aqueous solution," Russian Journal of Coordination Chemistry, vol. 33, no. 5, pp. 346-350, 2007.

[28] S. Rode, C. Henninot, and M. Matlosz, "Complexation chemistry in nickel and copper-nickel alloy plating from citrate baths," Journal of the Electrochemical Society, vol. 152, no. 4, pp. C248-C254, 2005.

[29] Y. Xuetao, W. Yu, S. Dongbai, and Y. Hongying, "Influence of pulse parameters on the microstructure and microhardness of nickel electrodeposits," Surface and Coatings Technology, vol. 202, no. 9, pp. 1895-1903, 2008. 

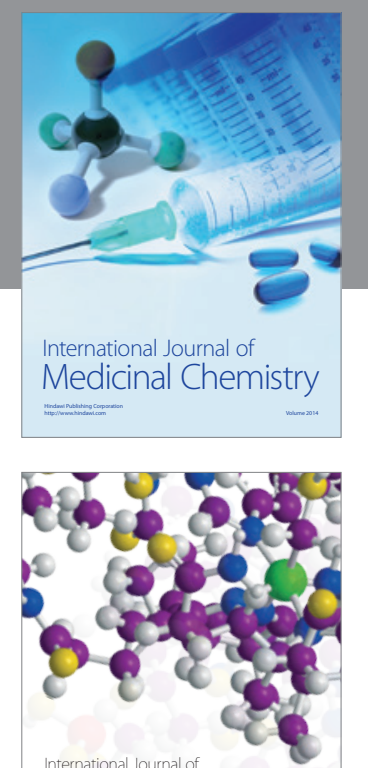

\section{Carbohydrate} Chemistry

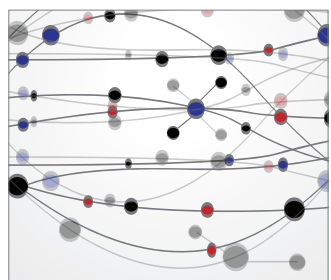

The Scientific World Journal
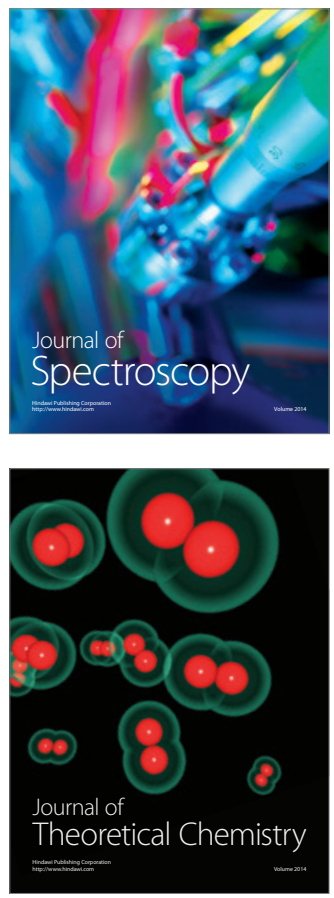
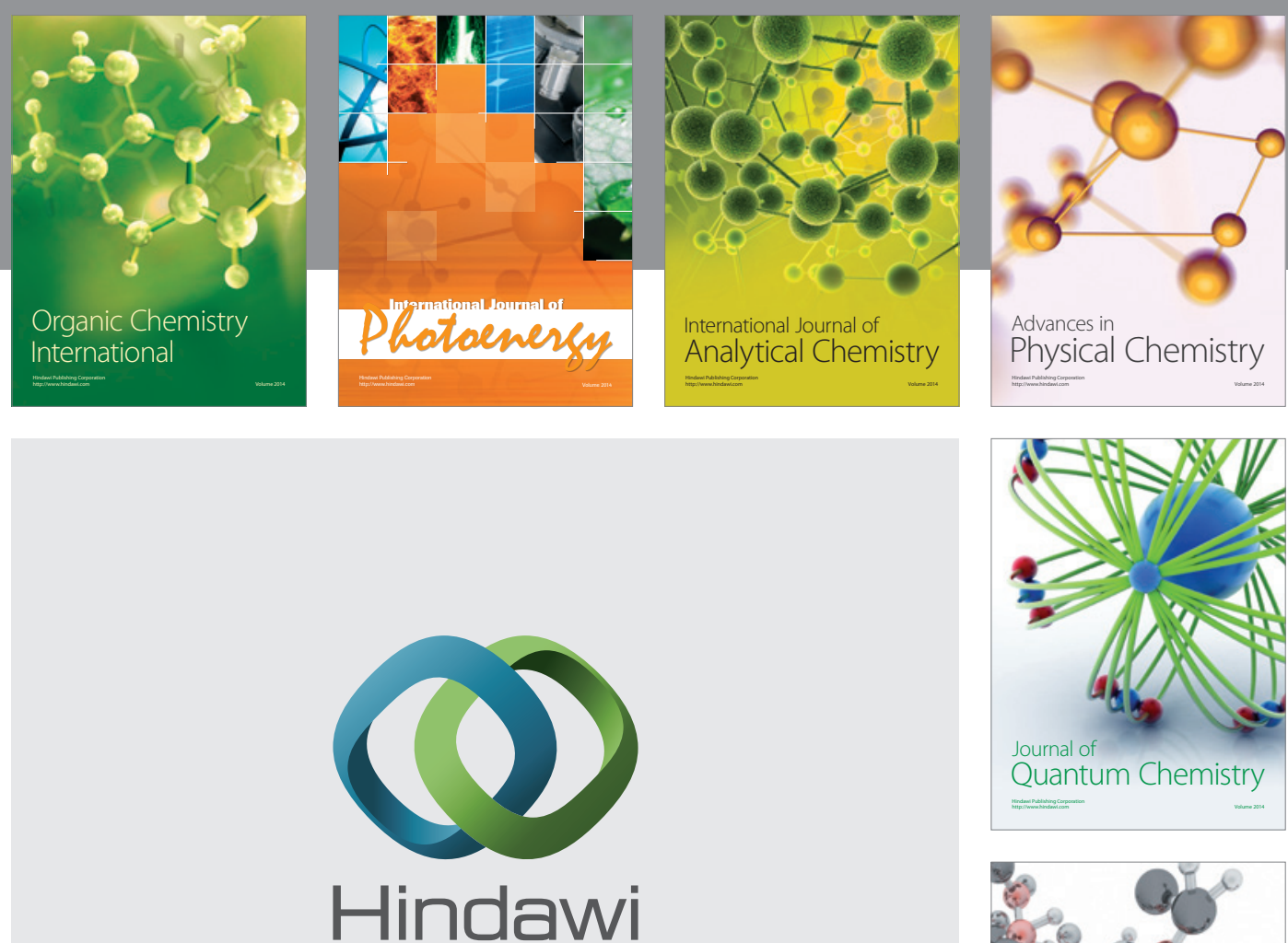

Submit your manuscripts at

http://www.hindawi.com

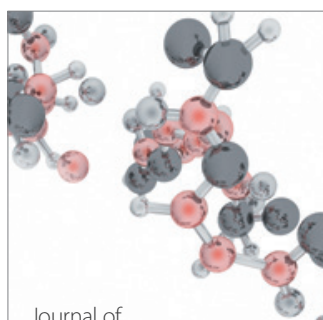

Analytical Methods

in Chemistry

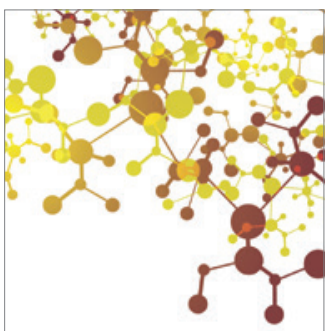

Journal of

Applied Chemistry

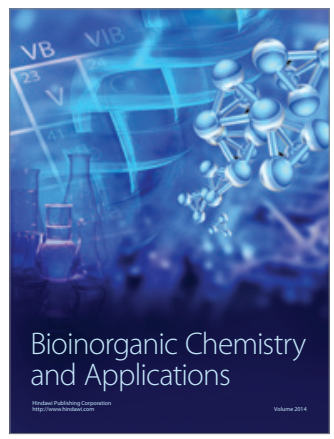

Inorganic Chemistry
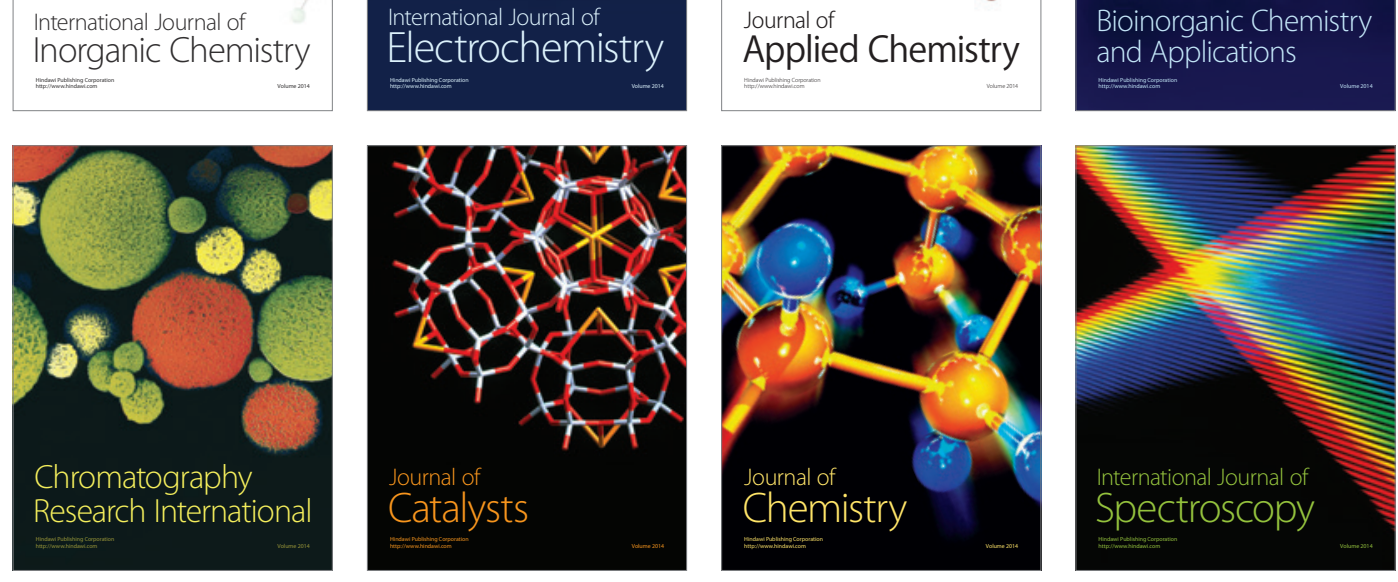